\title{
SEMIOTICS AND HERMENEUTICS: \\ DESIGNING A SEMIOTIC-BASED APPROACH \\ TO THEORIES OF INTERPRETATION
}

\section{Andreichuk N. I.}

\section{There is more work in interpreting interpretations than in interpreting things (Michel de Montaigne)}

\section{INTRODUCTION}

The critics of semiotics claim that this science has no unified subject matter and can be considered just an interesting hermeneutic practice and not entitled to conceive of itself as a scientific discipline. This article advocates the opinion that semiotics does have a unified subject as well as the status of a scientific discipline: it studies semiosis, that is the action of signs or the process in which something functions as a sign and a potentially endless series of interpretants is generated. Signs being a part of a developing process of information and understanding attached to particular objects ${ }^{1}$, semiosis is actually the action an interpreter must perform in understanding the signs. Interpretation as a problem or even as an explicit issue has tended to become a central concern in both: semiotics and hermeneutics since the earliest treatises on interpretation came forth. Generally acknowledged definition of hermeneutics as "the science of interpretation" "reflects the leitmotif of this science which deals with the processes of human understanding and interpretation of texts. Thus the notion of interpretation has always been across the two theories: theory of signs and theory of interpretation. As language is "the fundamental mode of operation of our being-in-the-world and the all-embracing form of the constitution of the world"3 the article substantiates the inseparable unity of lingual semiotic and hermeneutic studies in the context of the interpretation process. For hermeneutics language is not simply, as modernism believed, a mere means of communication but rather, between word and object there exists an "intimate unity": "The interpreter does not use words and concepts like a craftsman who picks up his tools and then puts them away.

\footnotetext{
${ }^{1}$ Atkin A. Peirce. London and New York : Routledge. 2016. P. 131-132.

${ }^{2}$ International Encyclopedia of Communications : in 4 vols. New York, Oxford : Oxford University press. 1989. Vol. 2. P. 343.

${ }^{3}$ Gadamer H.-G. Philosophical Hermeneutics. Trans. and ed. by David E. Linge. Berkley : University of California Press. 1976. P. 3.
} 
Rather we must recognize that all understanding is interwoven with concepts and reject any theory that does not accept the intimate unity of

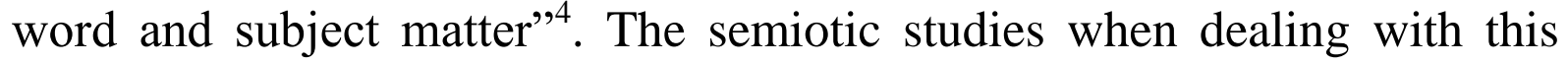
unity enrich and complement the ideas concerning the interpretation and understanding of texts that are fundamental to hermeneutic research.

The research in the field of hermeneutics is by its very nature informed by semiotic thought, although this link is not often made explicit in scholarly writings. The only attempt of the imposition of the conceptual web of philosophical hermeneutics and principles of the theory of signs on the historical data was made by Gustav Shpet in 1918 but unfortunately this paper was published only 70 years later ${ }^{5}$.

\section{The Notion of Interpretation: hermeneutic dimension}

Hermeneutics began not as the contemplation of essences, not even as a methodology of interpretation, but as the practical matter of transmitting messages. The Greek word hermeios referred to the priest at the Delphic oracle. This word and the more common verb hermeneuein and noun hermenneia point back to the wing-footed messenger-god Hermes, from whose name the words are apparently derived. In "Classical and Philosophical Hermeneutics" (a fairly detailed history of hermeneutics from ancient times to the present which was written as an encyclopedia article) ${ }^{6}$ Hans-Georg Gadamer (1900-2002) points out that hermeneutics is a term that covers many different levels of reflection, as is frequently the case with Greek words that have become part of the terminology in different scholarly disciplines. He mentions that even in the earliest Greek usage of the word hermenneia and hermēneuein there is a certain ambiguity. Hermes was the messenger of gods who brought their messages to human beings. As he is depicted in Homer, Hermes literally repeated the same words that the gods had ordered him to tell a human person. But often, especially in ordinary usage, the business of the hermeneus (interpreter) was more precisely that of translating something foreign or unintelligible into the language everybody speaks and understands ${ }^{7}$. The Greeks credited Hermes with the discovery of language and writing - the tools which human understanding employs to grasp meaning and to convey it to others. But Martin Heidegger, who sees philosophy itself as interpretation, does

\footnotetext{
${ }^{4}$ Gadamer H. G. Truth and method. Trans. by Joel Weinsheimer and Donald G.Marshall. London, New York : Continuum. 2004. P. 404.

${ }^{5}$ Шпет Г.Г. Герменевтика и ее проблемы. Констекст. М. 1989; Контекст. М. 1990; Контекст. М., 1991. URL: http://www.avorhist.ru/publish/shpet1.html

${ }^{6}$ Gadamer H.-G. Classical and Philosophical Hermeneutics. The Gadamer Reader : A bouquet of the Later Writings. Evanston, Illinois : Northwestern University Press. 2007. P. 44-71.

${ }^{7}$ Gadamer H.-G. Classical and Philosophical Hermeneutics. The Gadamer Reader : A bouquet of the Later Writings. Evanston, Illinois : Northwestern University Press. 2007. P. 44.
} 
not connect hermeneutics with Hermes. When asked about the word hermeneutics in his dialogue with a Japanese ${ }^{8}$, he obliquely says that "the noun hermeneus is referable to the name of the god Hermes by a playful thinking that is more compelling than the rigor of science"".

Thus, traced back to their earliest known root words in Greek, the origins of the modern words hermeneutics and hermeneutical suggest the process of "bringing to understanding" especially as this process involves language, since language is the medium par excellence in the process. In his "Hermeneutics" Richard Palmer emphasizes that the mediating and messagebringing process of "coming to understand" is implicit in all of the three basic directions of meaning of hermēneuein and hermēneia in ancient usage. These three directions, using the verb form (herméneuein) are: 1) to express something aloud in words, that is, to say; 2) to explain, as in explaining a situation; and 3) to translate, as in the translation of a foreign tongue ${ }^{10}$. All the three meanings may be rendered by the English verb "to interpret", yet each constitutes an independent meaning of interpretation.

Commonly scholars single out three stages of the development of interpretation as a specific technique used in humanities: 1) objectively practiced procedure developed by ancients in the framework of interpreting literary pieces of classical heritage in Greek antiquity, like oracles, dreams, myths, philosophical and poetical works, and also laws and contracts; 2) cultivated technique which was vital for the Christian culture of Middle Ages and constituted exegetics; 3) method and explicitly formulated problem in the philosophy of hermeneutics emerging from the contemplation of the procedures of understanding ${ }^{11}$.

At the third stage several different approaches can be singled out. Hermeneutics as a particular theory of text interpretation emerged in the modern period with the work of a German philosopher Friedrich Schleiermacher (1768-1834). He is commonly called the father of modern hermeneutics as he raised hermeneutical inquiry onto a universal level and opened up the problem of interpretation to a new world of understanding and explanation ${ }^{12}$.His hermeneutics performs a double task: to study the text as a product of a certain language system and the unique subjectivity behind it. The first task is performed by "objective" or grammatical interpretation and the second by "technical" or psychological one.

\footnotetext{
${ }^{8}$ It is worth mentioning that since Socrates' time a philosophical dialogue has been designed to provide the participants the opportunity to brood over different spheres of reality.

${ }^{9}$ Heidegger M. A dialogue on language (between a Japanese and an inquirer). On the way to language. Trans. by Peter D. Hertz. New York : Harper \& Row. 1971. P. 1-54.

${ }^{10}$ Palmer R. E. Hermeneutics. Evanston, Illinois : Northwestern University Press. 1969. P. 13.

11 Можейко М.А. Интерпретация. Новейший философский словарь. URL: https://www.gumer.info/ bogoslov_Buks/Philos/fil_dict/294.php

${ }_{12}$ Rutt J. On hermeneutics. E-LOGOS/2006. URL: https://nb.vse.cz/kfil/elogos/student/rutt.pdf
} 
In the second half of the $\mathrm{XIX}^{\text {th }}$ century with Wilhelm Dilthey (1833-1911) hermeneutics got the status of method in humanities. He claimed that hermeneutics provides "methodology of understanding". Humanities "understand" as opposed to sciences that "investigate". Dilthey turns hermeneutics into epistemology of understanding and the subject of understanding becomes a universal methodology: "The process of understanding, insofar as it is determined by common conditions and epistemological means, must everywhere have the same characteristics"13. To the extent that rules can guide the understanding of the objectifications of life it constitutes interpretation and hermeneutics as the theory of interpretation relates to all human objectifications - that is, not only speech and writing, but also visual artistic expressions, more casual physical gestures as well as observable actions or deeds ${ }^{14}$.

Defining hermeneutics as ontology of understanding is attributed to Edmund Husserl (1859-1938) and Martin Heidegger (1889-1976). Ontology of understanding presents an alternative to epistemology of interpretation and is grounded on the ontological categories of the man's world of life (Lebenswelt) and individual being (Dasein).

With Hans-Georg Gadamer understanding becomes a separate subject of philosophical studies and hermeneutics becomes an autonomous part of philosophy - philosophy of understanding. He mostly dealt with hermeneutics in the context of communication. He claims that language is the universal horizon of hermeneutic experience and that the hermeneutic experience is itself universal. Hermeneutics concerns our fundamental mode of being in the world and understanding is thus the basic phenomenon in our existence.

Philosophy of hermeneutics emerging from the contemplation of the procedures of understanding can be identified as one of the three major intellectual trends in the $20^{\text {th }}$ century inquiry that underlies interpretation, the other two being structuralism and logicism ${ }^{15}$. Structuralism involves making use of the methods of structural linguistics or structural anthropology, particularly as they have been developed by Ferdinand de Saussure and Claude Lévi-Strauss. Logicism is associated with the science of logic as devised by Charles Sanders Pierce and his pupil Charles Morris. Both projects are considered to be the most influential semiotic projects and are inseperable from hermeneutics which in turn generates multiple perspectives in semiotic studies.

\footnotetext{
${ }^{13}$ Dilthey W. Hermeneutics and the Study of History. Selected Works. Vol. IV. Ed. by R.A. Makkreel and F. Rodi. Princeton, NJ : Princeton University Press. 1996. P. 237.

${ }^{14}$ Makkreel R. Wilhelm Dilthey. Standord Encyclopedia of Philosophy. URL: https://plato.stanford.edu/ entries/dilthey

15 Gardin J.-C. Semiotic trends in Archeology. Representations in Archeology. Bloomington: Indiana University Press. 1992. P. 87-104.
} 


\section{The notion of interpretation:}

\section{points of intersection of hermeneutic and semiotic dimensions}

Stages in the development of interpretation as a specific technique used in humanities and doctrines of interpretation developed in hermeneutics that were singled out in the previous paragraph when viewed in the context of the development of semiotic ideas show amazing parallelism and even interdependence of those ideas.

Starting with the generally accepted definition of semiotics as a theory of signs we should note that from the very beginning (Hippocrates and Parmenides in the fifth century B.C.) semeion was used as a synonym for tekmerion (evidence, proof or symptom) and an intrinsic connection between a semeion and what it signifies was claimed ${ }^{16}$. The theory of signs was variously developed by Epicureans and especially the Stoics, as a way of proceeding by inference from what is immediately given to the unperceived. The Greek doctrine of signification acquired the designation semeiotiké, from sēma 'sign', sēmeiōtikos 'observant of signs ${ }^{17}$. Thus in the philosophic systems of antiquity the problem of sign was treated in the context of the connection of words, things and their names which in gnoseology is generalized as the problem of correlations of signs and their denotata.

The conviction that the word is a sign of idea was developed by Aristotle (384-322 B.C.). He states that the sign is the evidential precondition of the existence of things and indicates that (1) in discussion about signification of words, one has to consider the relation or relations between three terms: words, affections of the mind and things; (2) significative words are such by convention ${ }^{18}$. Thus Aristotle's ideas, especially his Peri Hermeneias (about 355 B.C.) ${ }^{19}$ may be read as an attempt to distinguish between words, intelligible significata and denotata. The fundamental question of sign, knowledge and interpretation is brought to the fore. Some scholars even believe that Aristotle actually made the first attempt to establish the connection between signification and interpretation, and can be called the father of "grammatical interpretation",20.

${ }^{16}$ Colapietro V. M. Glossary of Semiotics. New York : Paragon House. 1998. P. 185.

${ }^{17}$ Sebeok T. A. 'Semiotics' and its congeners. Studia z historii semiotyki : III Semiotic-historical studies. Ed. by J. Sulowsky. Wrocław, Warszawa, Kraków, Gdańsk: Wydawnictwo Polskiej Akademii nauk. 1976. P. 27.

${ }^{18}$ Аристотель. Первая аналитика. Глава 27. Сочинения в четырех томах. Ред. 3. Н. Микеладзе. М : Мысль, Т.2. 1978. С. 252-254.

${ }^{19}$ Аристотель. Об истолковании. (Герменевтика). Сочинения в четырех томах. Ред. 3. Н. Микеладзе. М : Мысль. 1978. Т. 2. С. 93-116.

${ }^{20}$ Бернюков А. Дометодологічний етап розвитку герменевтичних вчень. Університетські наукові записки. Хмельницький : Хмельницький ун-т управління та права, 2006. № 2 (18). С. 413. 
It was in Middle Ages that the ideas of hermeneutics and semiotics were explicitly brought together in St. Augustine's (354-430 A.D.) De Doctrina Christiana. He is also believed to be the first with whom we reach an explicit fusion of the theory of sign and the theory of language and whose "rigorous and important theoretical development remains unmatched for at least the following fifteen centuries, until Saussure's Cours de linguistique générale is written" ${ }^{21}$. Actually, Augustine never intended to create a theory of signs. He wanted to work out rules for interpreting Biblical texts and to discover the sense of the Holy Scripture so as to be able to explain it "to earnest students of the word, that they may profit not only from reading the works of others who have laid open the secrets of the sacred writings, but also from themselves opening such secrets to others",22. But his "semiotic" approach actually turned out to be an "introduction" to hermeneutics: "All instruction is either about things or about signs; but things are learnt by means of signs" ${ }^{\text {23 }}$. Augustine's classical definition of sign: something which besides manifesting itself to the senses also indicates to the mind something beyond itself - is wide enough to make everything accessible to the human mind an object of semiotics. It should be mentioned that certain elements differentiate Augustin's treatment of semiotic material from that of the Stoics. The Stoics formalized a long tradition rooted principally in medicine and divination, they considered only non-verbal signs, such as the smoke that reveals the fire or the scar which refers to the previous wound to be true signs. And Augustine was the first to study expressions of spoken language as signs: "We call signs in general everything that means something, and among them we may include words too" 24 . He points out the conventional character of signs and defines them as "those which living beings mutually exchange for the purpose of showing, as well as they can, the feelings of their minds, or their perceptions, or their thoughts. Nor is there any reason for giving a sign except the desire of drawing forth and conveying into another's mind what the giver of the sign has in his own mind"25. Augustine discusses different classes of signs, including the signs which have been given to us by God, and which are contained in the Holy Scripture and were made known to us through men - those, namely, who

\footnotetext{
${ }^{21}$ Manetti G. Theories of the Sign in Classical Antiquity. Trans. Ch. Richardson. Bloomington : Indiana University Press. 1993. P. 157.

${ }^{22}$ Augustine. On Christian Doctrine. Book I. URL: https://faculty.georgetown.edu/jod/augustine/ddc1.html

${ }^{23}$ Augustine. On Christian Doctrine. Book I. URL: https://faculty.georgetown.edu/jod/augustine/ddc1.html

${ }^{24}$ A detailed analysis can be found in Charles Connagham PhD dissertation: Connagham Ch. Signs, Language, and Knowledge in St. Augustine's De Magistro". URL: http://discovery.ucl.ac.uk/1445358/ 1/U592678.pdf

${ }^{25}$ Augustine. On Christian Doctrine. Book II. URL: http://www9.georgetown.edu/faculty/jod/augustine/ ddc2.html
} 
wrote the Scripture. Assuming that no one uses words except as signs of something else, he dwells upon cases when two or more interpretations are put upon the same words of the Scripture. He believes that any of the interpretations of the words should be in harmony with the truth. Thus St. Augustine raised quite a lot of issues that are fundamental for hermeneutics and with him hermeneutics has become coupled with semiotics.

John Deely drew attention to one more "neglected figure in the history of semiotic inquiry", who must be assigned a privileged position in semiotic historiography being the earliest systematizer of the doctrine of signs: John Poinsot (1589-1644) ${ }^{26}$. In his "Treatise on Signs" Poinsot points out that in our experience, signs bring together social and natural phenomena The sign is something neither preclusively natural nor preclusively social, but both inclusively. All signs as such acquire their signification and exist actually only within some living being's experience $^{27}$. This statement turns out to be of special importance to further development of the notion of interpretation, especially with Gadamer. Poinsot made "the actual first attempt to thematize philosophically the being proper to signs as the universal means of communication" 28 . He finds the ontology in our experience of the way in which things appear to be relative and this fundamental idea can be considered the foundation of explaining the nature of sigh through the philosophical category of relation $^{29}$. Thus Poinsot provided the semiotic approach to the hermeneutic problem of how we can come to know any reality, external to our minds, by showing that ideas in their existence as "private" (esse in) are transcendental relations serving to ground in their proper being (esse ad) relations to objects which by definition are accessible to many in communication and public life.

One more philosopher of the XVII ${ }^{\text {th }}$ century (much better known than John Poinsot) was John Locke (1632-1704) who actually injected the Greek word semeiotiké into the mainstream of English philosophical discourse. Locke declared the "doctrine of signs" to be a branch of his division of

\footnotetext{
${ }^{26}$ Deely J.N. Neglected figures in the history of semiotic inquiry : John Poinsot. History of semiotics. Ed. by Achim Eschbach, Jürgen Trabant. Amsterdam, Philadelphia : John Benjamins Publishing Company. 1983. P. 115-126.

${ }^{27}$ Deely J.N. Neglected figures in the history of semiotic inquiry : John Poinsot. History of semiotics. Ed. by Achim Eschbach, Jürgen Trabant. Amsterdam, Philadelphia : John Benjamins Publishing Company. 1983. P. 118 .

${ }^{28}$ Deely J.N. Neglected figures in the history of semiotic inquiry : John Poinsot. In History of semiotics. Ed. by Achim Eschbach, Jürgen Trabant. Amsterdam, Philadelphia: John Benjamins Publishing Company. 1983. P. 123.

${ }^{29}$ Андрейчук Н.I. Мовний знак через призму філософської категорії відношення. Наукові записки. Серія “Філологічна”. Острог : Видавництво національного університету “Острозька академія”. Вип. 26. 2012. С. 17-19.
} 
sciences: logic, physics and ethics. He treats words as signs of ideas and emphasizes that the work of mind consists in the perception of the meaning of those signs of ideas. Locke explains idea as the term denoting everything that is the object of human thought: "everything that human soul can be occupied with in the process of thinking" 30 . He treated words as sensory signs of ideas which people use "to show their ideas and to exhibit them before others; and thus in their primary or immediate meaning words denote only ideas which are in the mind of the person who makes use of those words"31. In the context of interpretation, it is very important to highlight Locke's idea that we can use any signs to designate our ideas to ourselves but one and the same sign should refer to one and the same idea: "If the main goal of the language used to transform a message is to be understood, then words $<\ldots>$ are of little use for this goal if they do not generate the same idea in the hearer which they designate in the mind of the speaker" (cit. from ${ }^{32}$ ). Umberto Eco believes that Locke made an attempt to introduce philosophic common sense which might control natural language ${ }^{33}$. With Locke the attempts to explain the capacity to understand from the very beginning have had a semiotic dimension as he states that understanding is "the perception of the signification of signs" Locke was also the first to attract attention to the specificity of language systems in reference to the language - culture correlation. He emphasized the ability of mind to repeat, combine and multiply ideas and substantiated that people belonging to different cultures produce such combinations of ideas which other people do not possess because of differences in the modes of life and traditions. Undoubtedly, this idea is of great importance for the studies of cultural semiosis and for "communicative" theories of hermeneutics.

But it was only with Ferdinand de Saussure that the new science of semiology was conceived of as related to social psychology and devoted to the investigation of the general principles of signs. With this conceptual shift, Saussure established a unified discipline of broad theoretical scope. He defined the sign as the fundamental unit of linguistic analysis and a "two-sided psychological entity" linking a concept and a sound pattern ${ }^{35}$. The concept is not a thing in the world, but rather a mental image of that

\footnotetext{
${ }^{30}$ Локк Д. Сочинения : в 3-х т. Ред. И. С. Нарский, А. Л. Субботин; пер. с англ. А. Н. Савина. М. : Мысль, 1985. Т. 1. С. 95.

31 Локк Д. Сочинения : в 3-х т. Ред. И. С. Нарский, А. Л. Субботин; пер. с англ. А. Н. Савина. М. : Мысль, 1985. Т. 1. С. 462.

32 Эко У. Поиски совершенного языка в европейской культуре. Пер. с итал. и примечания А. Миролюбовой. СПб : “Александрия”. 2007. С. 218.

33 Эко У. Поиски совершенного языка в европейской культуре. Пер.с итал. и примечания А. Миролюбовой. СПб : “Александрия”. 2007. С. 296.

${ }^{34}$ Locke J. An Essay Concerning Human Understanding. URL: ftp://ftp.dca.fee.unicamp.br/pub/docs/ia005/ humanund.pdf

${ }^{35}$ Saussure F. de. Course in General Linguistics. Ed. by Ch. Bally, A. Sechehaye; transl. from French by W. Baskin. New York : Philosophical Library.1959. P. 66.
} 
thing. Similarly, the sound pattern is not a physical sound, rather it is the hearer's cognitive interpretation of a sound. The concept and sound pattern are thus both mental entities and independent of any external object. Since words are the prime example of conventional signs, Saussure focuses exclusively on the system of linguistic conventions (langue) that makes actual utterances (parole) understandable to language users. He considered langue a purely formal set of relations that conjoins the two components of the linguistic sign arbitrarily - the sensory signifier and the intelligible signified. The study of the signifier was to yield a set of oppositions (the phonological system) that provides sonorous substance with linguistic form. The study of the signified would be concerned with the semantic grid that segments extralinguistic reality into meaningful linguistic units (words). The language system can be understood as a sequence of linked signs: " $(w)$ hether we take the signified or the signifier, language has neither ideas nor sounds that existed before the linguistic system, but only conceptual and phonetic differences that have issued from the system"36. What was specially important for hermeneutic studies was the idea that sign context is more important than the idea or sound since the value of the sign may change without affecting its meaning or sound because a neighbouring sign has changed. The semantic value of every particular signified would be derived solely from its opposition to other signifieds coexisting with the grid.

Saussure's fundamental insight that behind every utterance there is a linguistic code shared by speakers, was dissiminated through Europe and provided both semiotic and hermeneutic studies with a theoretical focus. His approach was adopted and extended by Russian Formalists, the Prague Linguistic Circle, the Linguistic Circle of Copenhagen and Americal Structural Linguistics. It received major support from Claude Lévi-Strauss who developed the field of structural anthropology. Structuralism has been particularly influential in literary theory through the writings of of Roland Barthes, Umberto Eco and Jean Baudrillard. It has however, been subject to criticism, most notably by Michel Foucault, Jacques Derridaq, Julia Kristeva, Paul Ricoeur and Pierre Bourdieu.

Crucial for the development of hermeneutic theory was the critical reaction to Saussure and formalism by Mikhail Bakhtin (1895-1975) and his followers. Bakhtinians claimed that the dichotomy between langue and parole and the privileging of the abstract system over actual speech failed to account for the communicative nature of the language as a medium of exchange. For them every sign (utterance) was an ideological product, a

\footnotetext{
${ }^{36}$ Saussure F. de. Course in General Linguistics. Ed. by Ch. Bally, A. Sechehaye; transl. from French by W. Baskin. New York : Philosophical Library. 1959. P. 120.
} 
direct or oblique reply to other signs (utterances) in an ongoing dialogical process that is the culture of a given community. These ideas concerning a possibility of a "virtual" dynamic interaction between the reader and the author are central for hermeneutic analysis. The reader's state of mind and his or her culture provide a context for understanding and interpretation of the text. The word, the grammatical form, propositions, and statements separated from the utterance (from the speech act) are viewed as "technical signs" at the service of a signification that is only potential. The individuation and actualisation of this potential of language operated by the utterance allows us to enter an other "sphere of being": the "dialogical sphere" 37 . Such "dialogic" quality of signs embraces several aspects that set the Bakhtinian understanding of signs clearly apart from the structuralist notions. For the structuralist, words are units of language whose meanings are defined by their relationships to other words. From a Bakhtinian point of view, such properties characterise words only as objects of a particular social practice and as a product of a particular societal attitude to language. They are used to position the speakers with regard to their hearers. They also position the speaker in relation to the referential objects of speech. Finally, Bakhtin's view on sign-sign relationships is quite different from the Saussurean and post structuralist emphasis on distinction as the constitutive determinant of the sign. A poetic description of the sign's dialogic relationship to other signs can be found in his essay "Discourse in the Novel": "But no living word relates to its object in a singular way: between the word and its object, between the word and the speaking subject, there exists an elastic environment of other, alien words about the same object, the same theme, and this is an environment that it is often difficult to penetrate. The word, directed toward its object, enters a dialogically agitated and tension-filled environment of alien words, value judgements and accents, weaves in and out of complex interrelationships, merges with some, recoils from others, intersects with yet a third group" ${ }^{, 3}$. Trying to give an account of the sign as it appears to its user in the tasks of expressing oneself or trying to make sense of the other's utterance, reveals the potential of semiotic approach in hermeneutic studies.

\section{Theories of interpretation in semiotic perspective}

The second most notable programme for the general science of signs anglo-american pragmatism - was elaborated by US philosopher Charles

\footnotetext{
37 Lazzarato M. Mikhail Bakhtin's theory of the utterance. URL: http://www.generationonline.org/p/fp_lazzarato6.htm

${ }^{38}$ Bakhtin M. Discourse in the Novel. The Dialogic Imagination : Four Essays. Trans. by Michael Holquist and Caryl Emerson. Austin : University of Texas. 1981. P. 276.
} 
Sanders Peirce (1839-1914). His brilliant work was enormous in scope and can be viewed as a new insight into the interpretation process. In the article "How to Make Our Ideas Clear" that appeared in 1878 Peirce: "A clear idea is defined as one which is so apprehended that it will be recognized wherever it is met with, and so that no other will be mistaken for it. If it fails of this clearness, it is said to be obscure" ${ }^{39}$. The basic premise here is that an idea is only clear if it produces the effect of recognition. It is not enough for this effect to occur in an individual's consciousness. It must be experienced by a community of believers. For Peirce, all cognition is a semiotic process that is mediated by signs. To understand the meaning of a concept one needs to examine its various contexts of use. However, meaning can only be properly understood with reference to those logical concepts that establish a belief which in turn becomes a habit of thought. $\mathrm{He}$ explains these relationships as follows: "About forty years ago my studies of Berkeley, Kant and others led me, after convincing myself that all thinking is performed in signs, and that mediation takes the form of a dialogue, so that it is proper to speak of the "meaning" of a concept, to conclude that to acquire full mastery of that meaning it is requisite, in the first place, to learn to recognize the concept under every disguise, through extensive familiarity with instances of it" (cit. from ${ }^{40}$ ). For Pierce, semiosis - the action of sign - is an irreducibly triadic process in which an object generates a sign of itself and, in turn, the sign generates an interpretant of itself. A sign (representamen) thus: stands for something (its object); it stands for something to somebody (its interpretant); it stands for something to somebody in some respect (ground). These terms: representamen, object, interpretant and ground can thus be seen to refer to the means by which the sign signifies. The relationship between them determines the precise nature of the process of semiosis and must be read in two directions, firstly as determination, and secondly as representation: the object "determines" the interpretant, mediated by the sign, and both the sign and the interpretant "represent" the object. As Rick Parmentier says, these are "two opposed yet interlocking vectors involved in semiosis" If these vectors are brought into proper relations, then knowledge of objects through signs is possible. Thus the object is knowable through the sign, but semiosis mediates dynamically between the sign and what it is supposed to stand for. Though Peirce never mentioned hermeneutics in his

\footnotetext{
${ }^{39}$ Peirce Ch. S. How to Make Our Ideas Clear. Peirce on signs. Ed. James Hoopes. Chapel Hill and London : The University of North Carolina Press. 1991. P. 161.

40 'Pragmaticism'. Term in The Commens Dictionary : Peirce's Terms in His Own Words. Ed. by Bergman M., Paavola S. New Edition. URL: http://www.commens.org/dictionary/term/pragmaticism

${ }^{41}$ Parmentier R.J. Signs in Society : Studies in Semiotic Anthropology. Indiana University Press. 1994. P. 4.
} 
works his ideas concerning the interpretant of the $\operatorname{sign}^{42}$ can be applied for further development of the hermeneutic inquiry the focus of which is on the interpreter who is supposed to apprehend the ideas of the author in the process of interpretation. Three types of interpretant make the basis for defining three dimensions of semiosis ${ }^{43}$ and the latter can serve the basis for dividing semiotic studies into three groups (Fig. 1).
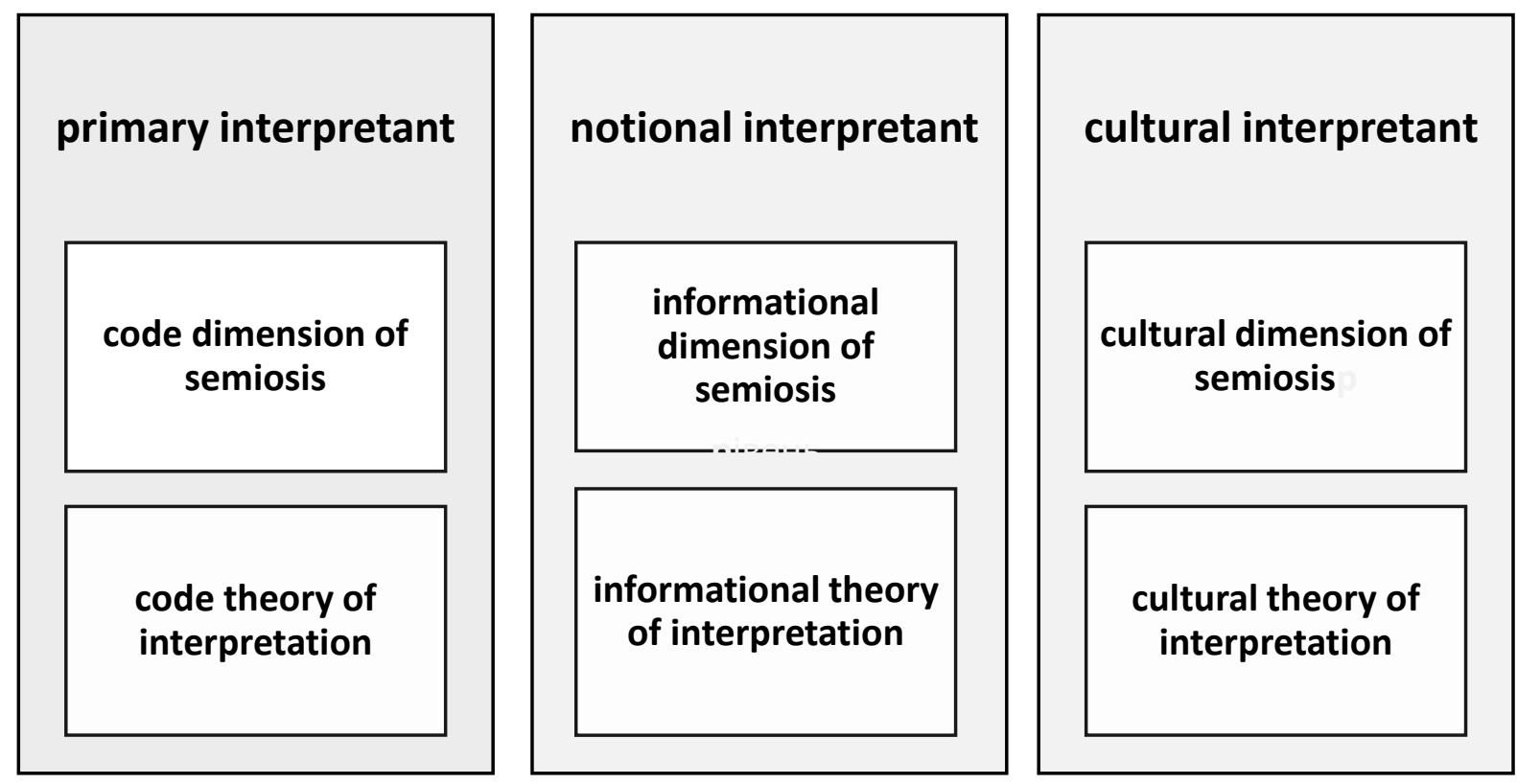

\section{Fig.1. The potential of the dimensions of semiosis for defining theories of interpretation}

Code theory of interpretation would see the text as a system of signs and include researches based on formal characteristics of signs. Informational theory of interpretation will try to find concepts, parameters and rules governing the transmission of messages through the text predetermined by its origin either in the mind of the author or by its social position. Cultural theory of interpretation will consider hidden meanings that are to be recognized according to a cultural key: mental stereotypes shaped by the culture.

\section{CONCLUSIONS}

A theory can be said to exist only when it is explicitly formulated as a theory. An explicit theory requires theoretical elaboration. Both hermeneutics and semiotics are explicitly developed theories of

\footnotetext{
42 For a more detailed analysis see Андрейчук H.I. Інтерпретанта як людський чинник мовного семіозису. Мовознавство. 2012. № 3. С. 65-74.

43 Андрейчук Н.I. Перечитуючи Ч. Морріса : перегляд вимірів семозосу. Любовь $к$ слову : филологические заметки в честь юбилея профессора В. А. Кухаренко : сборник научных статей. Одесса : КП ОГТ. 2018. С. 22-36.
} 
interpretation where the form of a theory is actually imposed on an activity which is eminently practical. Thus we can speak of 'a universal doctrine for the interpretation of signs'.

Since the very emergence of hermeneutics, semiotic ideas had much to offer those interested in the capacity of the language to mediate between a human speaker and a world of meanings. Moreover, the very notion of sign seems to have emerged in the context of the first attempts of ancients to analyze the process of understanding and interpreting messages. Even quite a brief engagement with this subject matter allows to claim that the concept of sign is like a skeleton or abstract key that allows us to move: (1) from Plato and Aristotle to Wilhelm Dilthey with whom hermeneutics got the status of method in humanities dealing with rules that guide the understanding of all human objectifications - different types of signs; (2) from St. Augustine who formulating the guide to interpreting the Holy Scripture suggested the "classical" definition of sign - to Charles Peirce a pioneer in the study of perception and thought, both of which he believed could be examined through a formal doctrine of signs; (3) from Locke who treated understanding as the perception of the signification of signs to Umberto Eco who studies all cultural processes as processes of communication that are permitted by an underlying system of signification $^{44}$.

Since the very emergence of ideas concerning the mechanism of interpretation the latter has always been across the two theories: theory of signs and theory of interpretation. Attention to the tradition of semiotic scholarship can enrich and substantiate assumptions about interpretation and understanding that have been developed in hermeneutics. The dynamic interaction between the sender and the receiver, which is crucial for hermeneutical studies can be revealed through the interpretation of the variability of linguistic signs and their interaction. Thus, the discoveries concerning the nature of sign and dimensions of semiosis which were elaborated in semiotics, allow to expose the mechanism of text interpretation through establishing ties between its sign embodiment and concrete "denotative" events and suggest three theories of interpretation: code, informational and cultural.

\section{SUMMARY}

Semiotic perspective for hermeneutic studies provides: 1) a certain "congeniality" of research in the field of text interpretation; 2) new vision of possible directions of universal hermeneutics development. The semiotic studies enrich and complement the ideas concerning the

\footnotetext{
${ }^{44}$ Eco U. A Theory of Semiotics. Bloomington : Indiana University Press. 1979. P. 8.
} 
interpretation and understanding of texts that are fundamental to hermeneutic research and the dynamics of the development of the concept of interpretation in all great hermeneutic and semiotic projects can provide the proof of semiotics - hermeneutics intersection.

The value of semiotic perspective is twofold - it offers a kind of unity to the disciplines dealing with interpretation of "mentalities" and it allows for new understandings of the progress for a universal hermeneutics as the art of dealing with time-bound, context-sensitive, interpreter-dependent dynamic processes.

At all the stages of the hermeneutic ideas development the role played by semiotic inquiry seems crucial. Hermeneutics, structuralism and logisim are brought together by the notion of the interpretation of signs elaborated in semiotics. Semiotic implication is broad enough to encompass the entire range of theories of interpretation. In particular, the notion of semiosis when viewed in three dimensions: code, informational and cultural provides the basis for distinguishing three types of the theories of interpretation. Code theories would encompass researches dealing with the "physical being" of the items participating in the interaction. Informational theories provide theoretical insights into the complex issues of understanding as a special concern of philosophers, psychologists and linguists and placed under the scrutiny of semiotic perspective. Cultural theories of interpretation bring into consideration evaluative modalities within sociocultural contexts that are embedded and transmitted by culture.

The suggested view on the theories of interpretation binds together humanities and social sciences in a wide semiotic perspective and offers condensation of descriptions into a universal doctrine for the interpretation of signs.

\section{REFERENCES}

1. Atkin A. Peirce. London and New York: Routledge. 2016. 314 p.

2. Augustine. On Christian Doctrine. Book I. URL: https://faculty.georgetown.edu/jod/augustine/ddc1.html

3. Augustine. On Christian Doctrine. Book II. URL: http://www9.georgetown.edu/faculty/jod/augustine/ddc2.html

4. Bakhtin M. Discourse in the Novel. The Dialogic Imagination: Four Essays. Trans. M. Holquist and C. Emerson. Austin: University of Texas. 1981. P. 259-422.

5. Colapietro V. M. Glossary of Semiotics. New York: Paragon House. 1998. 192 p. 
6. Connagham Ch. Signs, Language, and Knowledge in St. Augustine's De Magistro. URL: http://discovery.ucl.ac.uk/1445358/ 1/U592678.pdf

7. Deely J. N. Neglected figures in the history of semiotic inquiry: John Poinsot. History of semiotics. Ed. by Achim Eschbach, Jürgen Trabant. Amsterdam, Philadelphia: John Benjamins Publishing Company. 1983. P. 115-126.

8. Dilthey W. Hermeneutics and the Study of History. Selected Works. Vol. IV. Ed by R. A. Makkreel and F. Rodi. Princeton, NJ: Princeton University Press. 1996. 421 p.

9. Eco U. A Theory of Semiotics. Bloomington: Indiana University Press. 1979. $354 \mathrm{p}$.

10. Gadamer H.-G. Classical and Philosophical Hermeneutics. The Gadamer Reader: A bouquet of the Later Writings. Ed. by Richard E. Palmer. Evanston, Illinois: Northwestern University Press. 2007. P. 44-71.

11. Gadamer H.-G. Philosophical Hermeneutics. Trans. and ed. by David E. Linge. Berkley: University of California Press. 1976. 243 p.

12. Gadamer H.-G. Truth and method. Trans. by Joel Weinsheimer and Donald G. Marshall. London, New York: Continuum. 2004. 601 p.

13. Gardin J.-C. Semiotic trends in Archeology. Representations in Archeology. Bloomington: Indiana University Press. 1992. P. 87-104.

14. Heidegger M. A dialogue on language (between a Japanese and an inquirer). On the way to language. Trans. by Peter D. Hertz. New York: Harper \& Row. 1971. P. 1-54.

15. International Encyclopedia of Communications: in 4 vols. New York, Oxford: Oxford University press. 1989. Vol 2.

16. Lazzarato M. Mikhail Bakhtin's theory of the utterance. URL: http://www.generation-online.org/p/fp_lazzarato6.htm

17. Locke J. An Essay Concerning Human Understanding. URL: $\mathrm{ftp}: / / f t p . d c a . f e e . u n i c a m p$. br/pub/docs/ia005/humanund.pdf

18. Makkreel R. Wilhelm Dilthey. Standord Encyclopedia of Philosophy. URL: https://plato.stanford.edu/entries/dilthey/\#N190Hist UndeHerm

19. Manetti G. Theories of the Sign in Classical Antiquity. Trans. by Ch. Richardson. Bloomington: Indiana University Press. 1993. 196 p.

20. Palmer R. E. Hermeneutics. Evanston, Illinois: Northwestern University Press. 1969. 289 p.

21. Parmentier R. J. Signs in Society: Studies in Semiotic Anthropology. Indiana University Press. 1994. 225 p. 
22. Peirce Ch. S. How to Make Our Ideas Clear. Peirce on signs. Ed. by James Hoopes. Chapel Hill and London: The University of North Carolina Press. 1991. P. 160-179.

23. 'Pragmaticism'. Term in The Commens Dictionary: Peirce's Terms in His Own Words. Eds. Bergman M., Paavola S. New Edition. URL: http://www.commens.org/dictionary/term/pragmaticism

24. Rutt J. On hermeneutics. E-LOGOS/2006. URL: https://nb.vse.cz/ kfil/elogos/student/rutt.pdf

25. Saussure F. de. Course in General Linguistics. Ed. by Ch. Bally, A. Sechehaye; transl. from French by W. Baskin. New York: Philosophical Library. 1959. 240 p.

26. Sebeok T. A. 'Semiotics' and its congeners. Studia $z$ historii semiotyki: III Semiotic-historical studies. Ed. by J. Sulowsky. Wrocław, Warszawa, Kraków, Gdańsk: Wydawnictwo Polskiej Akademii nauk. 1976. P. 27-38.

27. Андрейчук H.I. Інтерпретанта як людський чинник мовного семіозису. Мовознавство. 2012. № 3. С. 65-74.

28. Андрейчук Н.I. Мовний знак через призму філософської категорії відношення. Наукові записки. Серія “Філологічна”. Острог: Видавництво національного університету "Острозька академія". Вип. 26. 2012. С. 17-19.

29. Андрейчук Н.I. Перечитуючи Ч.Морріса: перегляд вимірів семозосу. Любовь к слову: филологические заметки в честь юбилея профессора В.А. Кухаренко: сборник научных статей. Ред. И. М. Колегаева. Одесса: КП ОГТ. 2018. С. 22-36.

30. Аристотель. Об истолковании. (Герменевтика). Сочинения в четырех томах. Ред. З. Н. Микеладзе. М: Мысль. 1978. Т. 2. C. 93-116.

31. Аристотель. Первая аналитика. Глава 27. Сочинения в четырех томах. Ред. З. Н. Микеладзе. М: Мысль. 1978. Т. 2. C. 252-254.

32. Бернюков А. Дометодологічний етап розвитку герменевтичних вчень. Університетські наукові записки. Хмельницький: Хмельницький ун-т управління та права. 2006. № 2 (18). С. 411-417.

33. Локк Д. Сочинения: в 3-х m. Ред. И. С. Нарский, А. Л. Субботин; пер. с англ. А. Н. Савина. М.: Мысль. 1985. Т. 1. 621 с.

34. Можейко М. А. Интерпретация. Новейший философский словарь. URL: https://www.gumer.info/bogoslov_Buks/Philos/fil_dict/ 294.php 
35. Шпет Г. Г. Герменевтика и ее проблемы. Констекст. М. 1989; Контекст. М. 1990; Контекст. М., 1991. URL: http://www.avorhist.ru/ publish/shpet1.html

36. Эко У. Поиски совершенного языка в европейской культуре. Пер. с итал. и примечания А. Миролюбовой. СПб: “Александрия”. 2007. 423 c.

\section{Information about the author:} Andreichuk N. I., Doctor of Philology, Professor at Hryhoriy Kochur Department of Translation Studies and Contrastive Linguistics, Ivan Franko National University of Lviv 1, Universytetska str., Lviv, 79000, Ukraine 